amount of plasma equivalent to the patient's total plasma volume needs to be removed at roughly weekly intervals, and this has to be replaced with plasma substitutes. Many factors, moreover, probably contribute to the benefits of plasma exchange and we need further trials under controlled conditions to establish its real value.

\footnotetext{
${ }^{1}$ Bystryn, J C, Graf, M W, and Uhr, J W, fournal of Experimental Medicine, 1970, 132, 1279

2 Branda, R F, et al, Transfusion, 1975, 15, 570.

${ }^{3}$ Bystryn, J C, Schenkein, I, and Uhr, J W, Progress in Immunology I, ed B Amos, p 628. New York, Academic Press, 1971.

4 Lockwood, C M, et al, Lancet, 1976, 1, 711.

${ }^{5}$ Rossen, R D, et al, Clinical and Experimental Immunology, 1976, 24, 218

${ }^{6}$ Lang, C H, et al, Archives of Internal Medicine, 1977, 137, 1076.

7 Walker, R G, et al, Medical fournal of Australia, 1977, 1, 875.

${ }^{8}$ McPhaul, J J, and Dixon, F J, Fournal of Immunology, 1971, 107, 678.

${ }^{9}$ Churg, J, Morita, T, and Suzuki, Y, Glomerular Nephritis, Morphology, Natural History and Treatment, eds $\mathrm{P}$ Kincaid-Smith, T H Mathew, and E L Becker, p 677. New York, Wiley, 1973.

10 Verrier-Jones, J, et al, Lancet, 1976, 1, 709.

11 Clarke, C A, et al, Lancet, 1970, 1, 793.

12 Lindstrom, J M, et al, fournal of Experimental Medicine, 1976, 144, 739.

${ }_{13}$ Lindstrom, J M, et al, Neurology, 1976, 26, 1054.

14 Tokya, K V, et al, New England Fournal of Medicine, 1977, 296, 125.

15 Vincent, A, Pinching, A J, and Newsom Davis, J, Neurology, 1977, 27, 364.

16 Dau, P C, et al, New England fournal of Medicine, 1977, 297, 1134.

17 Pinching, A J, Peters, D K, and Davis, J N, Lancet, 1976, 2, 1373.

18 Finn, R, and Coates, P M, Lancet, 1977, 1, 190.

19 Newsom Davis, J, et al, New England fournal of Medicine, 1978, 298, 456.

${ }^{20}$ Cohen, M A, and Oberman, H A, Transfusion, 1970, 10, 58.
}

\section{Hyperbaric oxygen}

Although hyperbaric oxygen has a firmly established if small place in clinical practice, most doctors know little about it or where it can be obtained. The single-patient chamber filled with pure oxygen came into use in the United Kingdom during the 1960s. Sixteen of these are in radiotherapy centres in the UK with 27 other chambers in 22 hospitals* throughout Britain. A move to establish regional centres has resulted in three-at Heatherwood Hospital, Ascot, for the Oxford Region; at Whipps Cross Hospital for North London; and at Peterborough District Hospital for the Cambridgeshire area. Large, walk-in, multiplace chambers exist in Aberdeen, Wroughton, Glasgow, and Newcastle upon Tyne, and at the Institute of Naval Medicine at Alverstoke. In these the patients receive hyperbaric oxygen by face mask, the staff being pressurised with air. This type of chamber is more expensive to run. Britain is behind other countries in exploiting this method of

*King's College Hospital, London; St George's Hospital, Lincoln; Mount Vernon Hospital, Northwood; Cookridge Hospital, Leeds; The London Hospital; Westminster Hospital, London; Whipps Cross Hospital, London; Heatherwood Hospital, Ascot; Dorset County Hospital, Dorchester; Cheltenham General Hospital; Frenchay Hospital, Bristol; Royal Naval Hospital, Haslar; Royal Hants Hospital, Winchester; Good Hope Hospital, Sutton Coldfield; Princess Alexandra's Hospital, RAF Wroughton; Preston Hall Hospital, Maidstone; Isle of Thanet Hospital, Ramsgate; Northampton General Hospital; Peterborough District Hospital; Western Infirmary, Glasgow; Velindre Hospital, Cardiff; Royal Victoria Hospital, Belfast. treatment. Japan has over 100 treatment chambers in 80 centres, the Soviet Union at least 69, and Spain 33 (the most in terms of chambers per head of population). Over 70 units have been sold to the United States by British manufacturers. In the last two decades hyperbaric oxygen systems have been exported from Britain to 40 countries, during which time the numbers in the UK have not substantially increased.

The established indications for the use of hyperbaric oxygen include burns, ${ }^{1}$ carbon monoxide poisoning, ${ }^{2}$ decom- $-\stackrel{\vec{s}}{\stackrel{9}{9}}$ pression sickness, ${ }^{3}$ air embolism, and anaerobic infectionsnotably gas gangrene. ${ }^{4}$ Despite many published accounts of its $\frac{\bar{\sigma}}{\bar{\omega}}$ dramatic effects on Clostridium welchii infections, surgeons $\overrightarrow{\widetilde{\sigma}}$ still prefer the scalpel to the pressure chamber as the first line of attack in this lethal condition. The high $\mathrm{Po}_{2}$ within the chamber-about $2250 \mathrm{~mm} \mathrm{Hg}(299 \mathrm{kPa})$ at a pressure of three $\overrightarrow{0}$ atmospheres absolute-immediately stops the organism $\overrightarrow{\vec{H}}$ multiplying and inactivates the toxin while maintaining the viability of the damaged tissues. Carbon monoxide poisoning윽 is much less common than it was in Britain, because the North Sea gas now used contains no carbon monoxide. Paradoxically, however, the advent of North Sea gas, though it has reduced $\overrightarrow{0}$ the need for hyperbaric oxygen as a treatment for gas poisoning, has increased the demand for hyperbaric facilities $\vec{N}$ in hospitals close to the offshore rigs because of the conditionso of pressure in which the divers work.

There is a small demand for the method for handling sickle-cell crises and improving the viability of pedicle skino grafts, and a wider demand (with less predictable results) for treating ulcers of ischaemic origin and pressure sores. Hyperbaric oxygen has also been used successfully in chronic ${ }^{\infty}$ osteomyelitis $^{5}$ even though the causative organisms areo aerobic. The results of studies using the technique for treating myocardial infarction, ${ }^{6}$ for improving cognitive functioning in the aged, ${ }^{7}$ and for neurosurgery ${ }^{8}$ have proved encouraging. For these conditions, however, the place of oxygen at pressure remains uncertain.

Hyperbaric oxygen has thus earned itself a place in orthodox clinical practice. The method is not fully exploited in Britaingo but existing facilities would probably be adequate if they were properly coordinated throughout the country. Setting up thes three regional centres is a move in the right direction.

${ }^{1}$ Grossman, A R, and Yanda, R L, in Proceedings of the 5th Internationai Hyperbaric Congress, eds W G Trapp et al, p 300. Burnaby, Simon? Fraser University, 1973.

${ }^{2}$ British Medical fournal, 1970, 3, 180.

${ }^{3}$ Behnke, A R, and Shaw, L A, United States Naval Medical Bulletin, 1937, 35, 61 .

${ }^{4}$ Boerema, I, and Groeneveld, P H A, in Proceedings of the 4th Internationa Congress on Hyperbaric Medicine, eds J Wada and Iwa, T, p 255. London, Baillière, Tindall and Cassell, 1970.

5 Bingham, E L, et al, in Proceedings of the 5th International Hyperbario Congress, eds W G Trapp et al, p 264. Burnaby, Simon Fraser University, 1973.

6 Thurston, J G B, et al, Quarterly fournal of Medicine, 1973, 42, 751. 우

7 Jacobs, E A, Alvis, $\mathrm{H}$ J, and Small, S M, in Proceedings of the 5th Inter 60 national Hyperbaric Congress, eds W G Trapp et al, p 439. Burnaby, Simon Fraser University, 1973.

${ }^{8}$ Holbach, K H, and Gött, U, in Proceedings of the 4th International Congress on Hyperbaric Medicine, eds J Wada and T Iwa, p 441. London, Baillière Tindall and Cassell. 1970. 